\title{
Penerapan Algoritma Greedy Dalam Pencarian Jalur Terpendek Pada Instansi-Instasi Penting Di Kota Argamakmur Kabupaten Bengkulu Utara
}

\author{
Yulia Darnita ${ }^{1}$, Rozali Toyib ${ }^{2}$ \\ Alamat (Telp. (0736) 22765, Fax. (0736) 26161; e-mail: yuliadarnita@umb.ac.id) \\ ${ }^{1,2}$ Dosen Tetap Program Studi Teknik Informatika Fakultas Ilmu Teknik Universitas Muhammadiyah Bengkulu \\ J1. Bali Po. Box, 118 Kota Bengkulu 38119 Telp. (0736) 22765, Fax. (0736) 26161; e-mail: rozalitoyib@umb.ac.id)
}

\begin{abstract}
The search for important agencies in the city of Argamakmur is an important thing to be done by people who are from outside the region when they move in non-permanent (temporary) or permanent in one area, thus the difficulty in accessing distance and time is one of the things which needs to be considered in order to get information about where the right and accurate position of agencies. While searching, Greedy Algorithm works by finding the smallest spot point by calculating the route that is passed. Greedy Algorithm calculates the spot depends on the spot steps that have been passed and the spot at the stage itself. Based on the results of the system testing, it showed that: Local government takes the shortest time 10 minutes via Gunung Alam, Population and Civil Registration Agency (Capil) the shortest time is 10 minutes via Karang Suci, Resort Police Station (Polres) takes the shortest time 8 minutes via Bundaran, Fire Department takes the shortest time 10 minutes via Alun-alun, State Electricity Company (PLN) takes the shortest time 10-minute via Alun-alun, Regional General Hospital (RSUD) takes the shortest time about 6 minutes via Rama Agung. The shortest route can take longer time because of the crowds and density of the population. It needs adequate internet network to operate this system.
\end{abstract}

Keyword: Nearest Path Search, Institution, Distance, Greedy Algorithm.

Intisari- Pencarian instansi - instansi penting di kota argamakmur merupakan hal yang penting dilakukan oleh orang - orang dari luar daerah dalam melakukan perpindahan baik nonpermanen (sementara) atau permanen (menetap) di sebuah wilayah, dengan demikian bahwa faktor kesulitan dalam mengakses jarak serta waktu salah satu hal yang perlu di pertimbangkan agar mendapatkan informasi dimana letak posisi instansi - instansi yang tepat dan akurat. Pada saat pencarian, Algoritma Greedy bekerja dengan mencari titik bobot yang terkecil dengan menghitung rute yang dilewati dan Algoritma Greedy melakukan perhitungan bobot tergantung dari bobot tahapan yang telah dilewati dan bobot pada tahap itu sendiri. Berdasarkan hasil pengujian sistem yang dibuat : Pemda waktu tempuh 10 menit jalur terpendek gunung alam, Capil waktu tempuh 10 menit jalur terpendek karang suci, Porles waktu tempuh 8 menit jalur terpendek bundaran, Pemadam Kebakaran waktu tempuh 10 menit jalur terpendek alun - alun, PLN waktu tempuh 10 menit jalur terpendek alun - alun, Rumah Sakit Umum Daerah (RSUD) waktu tempuh 6 menit jalur terpendek Rama Agung, Adapun jalur terpendek bisa saja jarak tempuhnya lebih lama di karena keramaian dan kepadatan kependuduk untuk menjalankan sistem ini di butuhkan jaringan internet yang memadai.

Kata Kunci: Pencarian Jalur Terdekat , Instansi , Jarak, Algoritma Greedy.

\section{PENDAHULUAN}

Kabupaten Bengkulu utara dibentuk berdasarkan undang-undang darurat nomor 4 tahun 1956 tentang pembentukan daerah otonom kabupaten-kabupaten dalam lingkungan daerah propinsi Sumatera Selatan (lembaran negara tahun 1956 nomor 55, tambahan lembaran negara nomor 1091). dalam perkembangannya wilayah Kabupaten Bengkulu Utara telah mengalami dua kali pemekaran secara administratif terdiri dari 17 (tujuh belas) kecamatan yaitu Kecamatan Putri Hijau, Ketahun, Napal Putih, Batik Nau, Giri Mulya, Padang Jaya, Lais, Arga Makmur, Air Besi, Air Napal, Kerkap, Enggano, Hulu Palik, Air Padang, Tanjung Agung Palik Dan Ulok Kupai. Kabupaten Bengkulu Utara terletak antara $101^{\circ} 32^{\prime}-102^{\circ} 8^{\prime}$ bt dan $2^{\circ} 15-4^{\circ}$ ls memiliki 
luas wilayah 4.527,25 dengan ibukota kabupaten berada di Argamakmur dan Kabupaten Bengkulu Utara termasuk dalam wilayah program Transmigrasi Nasional.

Mobilitas penduduk adalah perpindahan penduduk dari suatu daerah ke daerah lain. mobilitas penduduk ada yang bersifat nonpermanen (sementara) ada pula mobilitas penduduk permanen (menetap), perpindahan penduduk dari suatu tempat ke tempat lain dengan melewati batas dengan tujuan untuk menetap. persebaran penduduk yang tidak merata antara desa dan kota membuat peningkatan penduduk yang berasal dari kota menjadi sangat signifikan tanpa diimbangi dengan jumlah lapangan pekerjaan, fasilitas umum, perumahan, aparat penegak hukum, penyedian pangan dan lain sebagainya. pengaruh-pengaruh tersebut bisa dalam bentuk mendorong, memaksa atau faktor pendorong seseorang untuk melakukan urbanisasi dan transmigrasi. pencarian instansi - instansi penting di kota argamakmur merupakan hal yang penting dilakukan oleh orang - orang dari luar daerah dalam melakukan perpindahan baik nonpermanen (sementara) atau permanen (menetap) di sebuah wilayah, dengan demikian bahwa faktor kesulitan dalam mengakses jarak serta waktu salah satu hal yang perlu di pertimbangkan agar mendapatkan informasi dimana letak posisi instansi - instansi yang tepat dan akurat,

Algoritma Greedy memiliki pendekatan untuk membangun solusi secara bertahap melalui urutan yang terus berkembang sampai solusi dari masalah telah tercapai. Greedy memberikan alternatif optimal lokal dengan harapan setiap alternatif lokal menghasilkan alternatif global yang optimal secara keseluruhan. Algoritma Greedy dapat menyelesaikan dengan menghitung nilai lokal optimal dan mendapatkan nilai optimasi global pada akhirnya [1].

Algoritma Greedy dengan knapsack problem untuk membantu proses optimasi terhadap pencarian waktu terpendek untuk mencapai tujuan dan pada setiap langkahnya merupakan pilihan, untuk membuat langka optimum lokal dengan harapan bahwa langkah sisahnya mengarah ke solusi optimum global [2].

\section{Tinjauan Pustaka}

\section{A. Algoritma Greedy}

Algoritma Greedy dapat menentukan jalur mana yang akan diambil terlebih dahulu atau dapat disebut dengan jalur optimum lokal sehingga sampai seluruh jalur diambil pada akhir perjalanan dan menciptakan rute perjalanan terpendek atau disebut dengan optimum global [3].

Algoritma greedy adalah algoritma yang memecahkan masalah langkah demi langkah, pada setiap langkah :

a. Mengambil pilihan yang terbaik yang dapat diperoleh saat itu

b. Berharap bahwa dengan memilih optimum local pada setiap langkah akan mencapai optimum global. Algoritma greedy mengasumsikan bahwa optimum lokal merupakan bagian dari optimum global.

Persoalan optimasi dalam konteks algoritma greedy disusun oleh elemen-elemen sebagai berikut:

a. Himpunan kandidat, $\mathrm{C}$.

Himpunan ini berisi elemen-elemen pembentuk solusi. Pada setiap langkah, satu buah kandidat diambil dari himpunannya.

b. Himpunan solusi, S. Merupakan himpunan dari kandidat-kandidat yang terpilih sebagai solusi persoalan. Himpunan solusi adalah himpunan bagian dari himpunan kandidat.

c. Fungsi seleksi - dinyatakan sebagai predikat SELEKSI - merupakan fungsi yang pada setiap langkah memilih kandidat yang paling mungkin untuk mendapatkan solusi optimal. Kandidat yang sudah dipilih pada suatu langkah tidak pernah dipertimbangkan lagi pada langkah selanjutnya.

d. Fungsi kelayakan (feasible) - dinyatakan dengan predikat LAYAK - merupakan fungsi yang memeriksa apakah suatu kandidat yang telah dipilih dapat memberikan solusi yang layak, yakni kandidat tersebut bersama-sama dengan himpunan solusi yang sudah terbentuk tidak melanggar kendaara yang ada.

e. Fungsi obyektif, merupakan fungsi yang memaksimumkan atau meminimumkan nilai solusi. 
Kita berharap optimum global merupakan solusi optimum dari persoalan. Namun, adakalanya 2 optimum global belum tentu merupakan solusi optimum (terbaik), tetapi dapat merupakan solusi sub-optimum atau pseudooptimum [4].

\section{B. Pencarian (Searching)}

Pada dasarnya teknik searching (pencarian) dapat dibagi menjadi 2 (dua) kelompoh yaitu: pencarian buta (blind search) dan pencarian terbimbing (heuristic search) [5]. Untuk mengukur peforma mentode pecarian, terdapat empat criteria yang dapat dilakukan adalah :

1. Completeness: apakah metode tersebut menjamin penemuan solusi jika solusinya memang ada?

2. Time cmplexity: berapa lama waktu yang diperlukan?

3. Space complexity: berapa banyak memori yang diperlukan?

4. Otimality: apakah metode tersebut menjain menemukan solusi yang terbaik jika terdapat beberapa solusi yang berbeda?

\section{Jalur Terpendek}

lintasan terpendek antara dua atau beberapa simpul lebih yang berhubungan. Persoalan mencari lintasan terpendek di dalam graf merupakan salah satu persoalan optimasi. Persoalan ini biasanya direpresentasikan dalam bentuk graf. Graf yang digunakan dalam pencarian lintasan terpendek atau shortest path adalah graf berbobot (weighted graph), yaitu graf yang setiap sisinya diberikan suatu nilai atau bobot. Bobot pada sisi graf dapat menyatakan jarak antar kota, waktu pengiriman pesan, ongkos pembangunan, dan sebagainya [6].

Lintasaan terpendek dapat di cari dengan memodelkan jaingan jalan ke sebuah graf. Graf yang digunakan adalahgraf berbobot, yaitu graf yang setiap sisinya memilikinilai atau bobot [7].

\section{Instansi}

Instansi adalah badan atau lembaga pemerintah/negara termasuk juga badan usaha milik negara (Penjelasan Pasal 19 Angka 2 UU Nomor 56 Tahun 1999 Tentang Rakyat Terlatih), lembaga negara, kementerian dan lembaga pemerintah nonkementerian, pemerintah provinsi, pemerintah kabupaten/kota, dan Badan Hukum Milik Negara/Badan Usaha Milik Negara yang mendapat penugasan khusus Pemerintah. Adapun instansi penting di Kota Argamakmur yang peneliti pilih adalah sebagai berikut : Kantor Pemda , Capil, Porles, Pemadam Kebakaran, PLN dan RSUD [8].

E. Global Positioning System (GPS)

Pengertian GPS Global Positioning System (GPS) merupakan sistem navigasi yang berbasiskan satelit dan merupakan alat untuk mengetahui posisi yang tersusun atas constellation 24 satellites yang mengorbit pada bumi pada ketinggian kurang lebih 11.000 mil. Awalnya GPS hanya terbatas untuk kalangan militer di USA, tetapi pada awal tahun 80an pemerintah membuatnya terbuka untuk digunakan secara umum khususnya pada komersial bisnis, travel, dan navigasi, sampai sekarang GPS sudah meluas penggunaannya seperti mendeteksi gempa dan ramalan cuaca. GPS didesain untuk beroperasi 24 jam, dalam segala kondisi cuaca dan bisa digunakan di seluruh dunia [9].

GPS adalah singkatan dari Global Positioning System, yang merupakan sistem navigasi dengan menggunakan teknologi satelit yang dapat menerima sinyal dari satelit. Cara kerja GPS secara logik ada 5 langkah:

1. Memakai perhitungan "triangulation" dari satelit.

2. Untuk perhitungan "triangulation", GPS mengukur jarak menggunakan travel time sinyal radio.

3. Untuk mengukur travel time, GPS memerlukan memerlukan akurasi waktu yang tinggi.

4. Untuk perhitungan jarak, kita harus tahu dengan pasti posisi satelit dan ketingian pada orbitnya.

5. Terakhir harus mengoreksi delay sinyal waktu perjalanan di atmosfer sampai diterima reciever

[10].

\section{III.Metodologi Penelitian}

\section{A. Flowchart}

Dari proses gambar 2 inisialisasi membentuk nilai matriks yang ditunjukkan pada tabel. Nilai matriks ini digunakan untuk menganalisasi apakah nilai yang ada pada matriks tersebut dihitung dalam mencari optimasi rute atau tidak. Pada awal perhitungan semua nilai akan 
diinisialisasikan ke nilai 1. Apabila nilai tersebut sudah dihitung maka program akan merubahnya menjadi 0 dan tidak akan dihitung lagi dalam perhitungan selanjutnya.

\section{B. Analisis Manual}

Dari data waktu tempuh yang didapatkan dari google maps maka berikut adalah tabel data yang didapatkan dan contoh perhitungan manual dengan algoritma greedy.

Tabel 1. Perhitungan Manual

\begin{tabular}{|c|c|c|c|c|c|c|}
\hline X & A & B & C & D & E & F \\
\hline A & X & 3 & 4 & 6 & 23 & 30 \\
\hline B & 3 & X & 1 & 7 & 25 & 32 \\
\hline C & 4 & 1 & X & 8 & 26 & 33 \\
\hline D & 6 & 6 & 7 & X & 19 & 28 \\
\hline E & 18 & 20 & 21 & 16 & X & 17 \\
\hline F & 29 & 31 & 32 & 27 & 17 & X \\
\hline
\end{tabular}
A. Kantor Pemda
B. Capil
C. Polres
D. Pemadam Kebakaran
E. PLN
F. RSUD

Dari data tersebut di misalkan total alokasi yang dapat dimiliki adalah 6 jam (360 menit) dan perjalnan dimulai dari titik Kantor Pemda (A). Lokasi dan alokasi waktu masing - masing tempat yang akan di kunjungi adalah sebagai berikut :
a. Ducapil (B) : 200 menit $=3,33$ jam
b. Polres (C) : 120 menit $=2$ jam
C. Pemadam Kebakaran (D) : 60 menit $=1$ jam
d. $\quad \operatorname{RSUD}(\mathrm{F}): 120$ menit $=2$ jam

Model perhitungan pertama ini menjumlah waktu tempuh dan waktu kunjung terlebih dahulu, kemudian dicari nilai yang terkecil. Apbila instansi tersebut tidak dikunjungi maka tidak termasuk dalam perhitungan, titik yang terpilih sebagai titik awal perhitungan berikutnya.

Maka perhitungannya adalah sebagai berikut :

- $\quad \mathrm{A}-\mathrm{B}=3+200=203$ menit
- $\mathrm{A}-\mathrm{C}=4+120=124$ menit

- $\mathrm{A}-\mathrm{D}=6+60=66$ menit

- $\quad \mathrm{A}-\mathrm{F}=30+120=150$ menit

Dari perhitungan tersebut maka $\mathrm{A}-\mathrm{D}$ adalah nilai terkecil dan D titik yang dipilih. Maka sisa waktu yang di miliki menjadi 360 - 66 = 294 menit, kemudian perhitungan dilanjutkan dari titik $\mathrm{D}$.

- $\quad \mathrm{D}-\mathrm{B}=6+200=206$ menit

- $\quad \mathrm{D}-\mathrm{C}=7+120=127$ menit

- $\quad \mathrm{D}-\mathrm{F}=28+120=133$ menit

Dari perhitungan tersebut maka $\mathrm{D}-\mathrm{C}$ adalah nilai terkecil dan $\mathrm{C}$ titik yang dipilih. Maka sisa waktu yang dimiliki menjadi $294-127=167$ menit , kemudian perhitung dilanjutkan dari titik $\mathrm{C}$.

- $\quad \mathrm{C}-\mathrm{B}=1+200=201$ menit

- $\quad \mathrm{C}-\mathrm{F}=33+120=153$ menit

Dari perhitungan tersebut maka $\mathrm{C}-\mathrm{F}$ adalah nilai terkecil dan $\mathrm{F}$ titik yang di pilih, maka sisa waktu yang dimiliki menjadi $167-153=14$ menit. Kemudian perhitungan dilanjutkan dari titik $\mathrm{F}$.

- $\quad \mathrm{F}-\mathrm{B}=31+200=231$ menit

Hanya tersisa B yang belum dikunjungi tetapi waktu total waktu tidak dapat mencukupi sehingga perhitungan selesai, jadi titik $B$ tidak diperhitungkan maka rute perjalanan optimal yang memenuhi dengan perhitungan knapsack greedy adalah :
a. Polres : 120 menit
b. Pemadam Kebakaran : 60 menit
c. RSUD : 120 menit

Dengan total waktu kunjungan dan perjalanan adalah 355 menit / 5 jam 55 menit.

\section{IV.HaSil dan PembahasaAN}

\section{A. Hasil}

Berikut adalah tampilan interface aplikasi pencarian rute terpendek yang berjalan pada sistem operasi pada komputer.

1. Menu utama 
Pada menu utama ini aplikasi ini tampilan apabila aplikasi pencarian rute terpendek dijalankan terdapat tampilan utama berisi menu-menu berupa seperti : Rute Terpendek ,Daftar Instansi dan Tentang. Tampilan menu utama dan penjelasan pada tombol - tombol Rute Terpendek, Daftar Instansi dan Tentang pada aplikasi dapat dilihat pada seperti gambar berikut :

a. Rute Terpendek

Dimana rute terpendek ini terdapat beberapa Dropdown, Button Rute dan Tampilan Peta Google Maps yang sudah di design peta nya menggunakan titik koordinat yang dimana daftar peta tersebut adalah :
1. Kantor Pemda
2. Capil
3. Porles
4. Pemadam kebakaran
5. PLN
6. RSUD.

\section{ALGORITMA GREEDY}

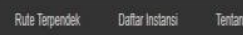

Pilih Tempat Asal dan Tempat yang Akan di Kunjungi

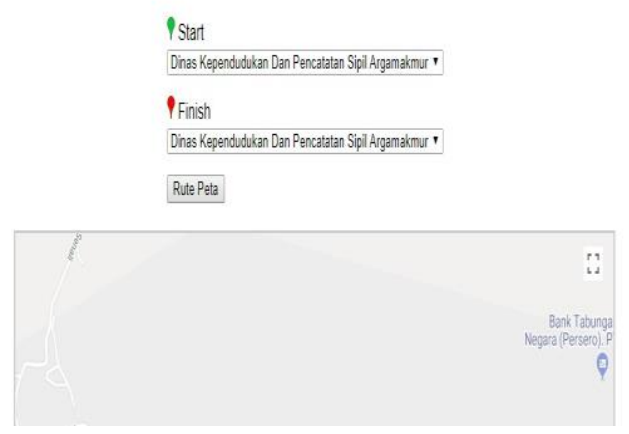

Gambar 1 Tampilan Menu Utama dan Rute Terpendek

b. Daftar Instansi

Pada menu Daftar Instansi ini, berupa instansi instansi sebagai berikut yaitu :

1. Instansi Kantor Pemda

2. Isntansi Capil

3. Instansi Porles

4. Instansi Pemadam Kebakaran

5. Instansi PLN
6. Instansi RSUD

Dimana sudah ditentukan di route dan diambil titik koodinatnya.

\section{ALGORITMA GREEDY}

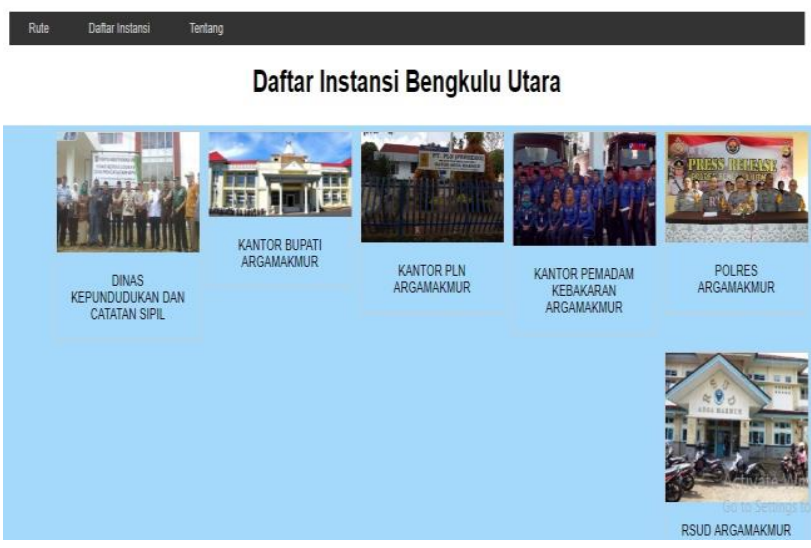

Gambar 2 Tampilan Menu Daftar Instansi

2. Menu Hasil Pencarian Rute Terpendek

Pada menu utama pada aplikasi Pencarian Rute Terpendek Instansi Penting Di Kota Argamakmur pada perangkat web di menu ini pengguna hanya akan memilih dari star. Berikut adalah hasil gambar dari Pencarian Rute :

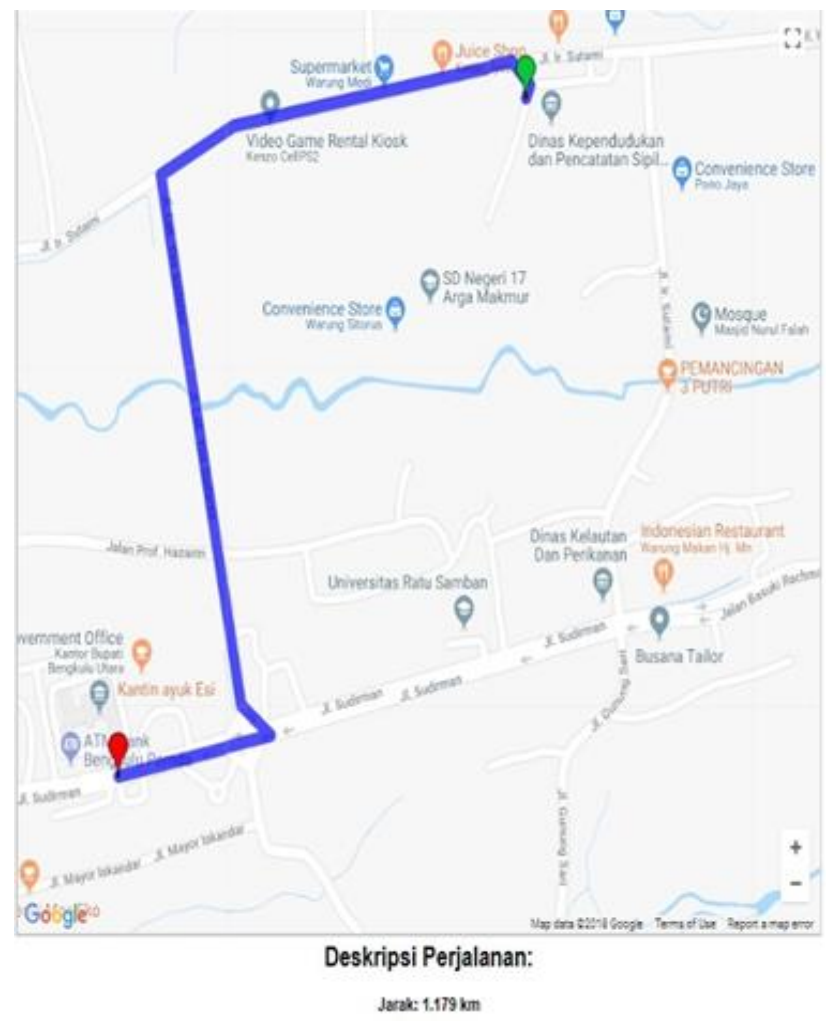

Gambar 3. Menu Hasil Pencarian Rute 
Pada saat pencarian, Algoritma Greedy bekerja dengan mencari titik bobot yang terkecil dengan menghitung rute yang dilewati dan Algoritma Greedy melakukan perhitungan bobot tergantung dari bobot tahapan yang telah dilewati dan bobot pada tahap itu sendiri.

Disaat titik koordinat awal yang telah ditentukan dengan klik data, aplikasi akan langsung menitik tempat yang dipilih sebagai koordinat, lalu kita memilih lokasi tujuan yang dimana. Titik koordinat telah di taging atau diambil disaat pembuatan aplikasi. Setelah itu, Algoritma Greedy langsung menghitung bobot setiap graf yang telah diambil sehingga mengeluarkan hasil seperti line/ garis sebagai solusi rute terpendek untuk dilalui.

\section{B. Pembahasan}

Tahapan pengujian dilakukan untuk mengetahui apakah aplikasi yang dibangun telah sesuai dengan yang diharapkan, untuk memastikan bahwa elemen-elemen atau komponen-komponen dari aplikasi telah berfungsi sesuai dengan yang diharapkan.

\section{Pengujian Black Box}

Pengujian Black Box adalah dimana program dianggap sebagai suatu kotak hitam yang berusaha menemukan fungsi-fungsi yang tidak benar atau hilang, kesalahan interface, kesalahan dalam struktur data atau akses database.

Tabel 2 Pengujian Black Box

\begin{tabular}{|c|c|c|c|c|c|}
\hline $\mathrm{N}$ & $\begin{array}{l}\text { Perse } \\
\text { dur } \\
\text { Peng } \\
\text { ujian }\end{array}$ & $\begin{array}{c}\text { Persedur } \\
\text { Pengujia } \\
\text { n }\end{array}$ & $\begin{array}{c}\text { Hasil } \\
\text { Yang } \\
\text { Dihara } \\
\text { pkan }\end{array}$ & $\begin{array}{l}\text { Hasil } \\
\text { penguji } \\
\text { an }\end{array}$ & $\begin{array}{l}\text { kesimpul } \\
\text { an }\end{array}$ \\
\hline 1 & $\begin{array}{l}\text { Rute } \\
\text { terpe } \\
\text { ndek }\end{array}$ & $\begin{array}{l}\text { Klik } \\
\text { plikasi } \\
\text { pencaria } \\
\text { n rute } \\
\text { terpeend } \\
\text { ek pada } \\
\text { perangka } \\
\text { t } \\
\text { komputer } \\
\text { untuk }\end{array}$ & $\begin{array}{l}\text { Muncul } \\
\text { splas } \\
\text { kemudi } \\
\text { an } \\
\text { muncul } \\
\text { halama } \\
\text { n menu } \\
\text { utama }\end{array}$ & $\begin{array}{l}\text { Sesuai } \\
\text { dengan } \\
\text { yang } \\
\text { diharap } \\
\text { kan }\end{array}$ & Valid \\
\hline
\end{tabular}

\begin{tabular}{|l|l|l|l|l|l|}
\hline & & $\begin{array}{l}\text { menjalan } \\
\text { kan } \\
\text { apliksi }\end{array}$ & & & \\
\hline 2 & Menu & Pilih & Tampil & Sesuai & Valid \\
daftar & salah & kan & dengan & \\
instan & satu & beberap & yang & \\
si & $\begin{array}{l}\text { lokasi } \\
\text { yang }\end{array}$ & $\begin{array}{l}\text { a menu } \\
\text { lokasi } \\
\text { akan } \\
\text { ditujuh }\end{array}$ & $\begin{array}{l}\text { instansi } \\
\text { penting }\end{array}$ & \\
kan & \\
pada & di kota & & \\
perangka & Argam & & \\
t & akmur & & \\
komputer & & & \\
\hline
\end{tabular}

\section{Pengujian}

Tabel 3. Pengujian

\begin{tabular}{|c|c|c|c|c|}
\hline $\mathrm{n}$ & $\begin{array}{c}\text { Kantor/Inst } \\
\text { ansi }\end{array}$ & Jalur & Waktu & $\begin{array}{c}\text { Jalur } \\
\text { Terpende } \\
\text { k }\end{array}$ \\
\hline 1 & $\begin{array}{l}\text { Kantor } \\
\text { Pemda }\end{array}$ & $\begin{array}{l}\text { 1. Jalur } \\
\text { Bundaran } \\
\text { 2. Jalur } \\
\text { Gunung } \\
\text { Alam }\end{array}$ & $\begin{array}{l}15 \mathrm{~m} \\
10 \mathrm{~m}\end{array}$ & $\begin{array}{l}\text { Jalur } \\
\text { Gunung } \\
\text { Alam }\end{array}$ \\
\hline 2 & $\begin{array}{l}\text { Kantor } \\
\text { Ducapil }\end{array}$ & $\begin{array}{l}\text { 1. Jalur } \\
\text { Karang } \\
\text { Suci } \\
\text { 2. Jalur } \\
\text { Gunung } \\
\text { Alam } \\
\text { 3. Jalur } \\
\text { lubuk } \\
\text { Saung }\end{array}$ & $\begin{array}{l}10 \mathrm{~m} \\
15 \mathrm{~m} \\
20 \mathrm{~m}\end{array}$ & $\begin{array}{l}\text { Jalur } \\
\text { Karang } \\
\text { Suci }\end{array}$ \\
\hline 3 & $\begin{array}{l}\text { Kantor } \\
\text { Polres }\end{array}$ & $\begin{array}{l}\text { 1. Jalur } \\
\text { Bundaran } \\
\text { 2. Jalur } \\
\text { Rama } \\
\text { Agung } \\
\text { 3. Jalur Pasar }\end{array}$ & $\begin{array}{l}8 \mathrm{~m} \\
13 \mathrm{~m} \\
20 \mathrm{~m}\end{array}$ & $\begin{array}{l}\text { Jalur } \\
\text { Bundara } \\
\mathrm{n}\end{array}$ \\
\hline
\end{tabular}




\begin{tabular}{|c|c|c|c|c|}
\hline 4 & $\begin{array}{l}\text { Kantor } \\
\text { Pemadam } \\
\text { Kebakaran }\end{array}$ & $\begin{array}{l}\text { 1. Jalu } \\
\text { r Rama } \\
\text { Agung } \\
2 . \quad \text { Jalu } \\
\text { r Pasar } \\
\text { 3. Jalu } \\
\text { r Alun- } \\
\text { alun }\end{array}$ & $\begin{array}{l}20 \mathrm{~m} \\
15 \mathrm{~m} \\
10 \mathrm{~m}\end{array}$ & $\begin{array}{l}\text { Jalur } \\
\text { Alun- } \\
\text { alun }\end{array}$ \\
\hline 5 & $\begin{array}{l}\text { Kantor } \\
\text { PLN }\end{array}$ & $\begin{array}{l}\text { 1. Jalur } \\
\text { Gunung } \\
\text { Alam } \\
\text { 2. Jalur } \\
\text { Alun-alun } \\
\text { 3. Jalur } \\
\text { Bundaran }\end{array}$ & $\begin{array}{l}25 \mathrm{~m} \\
10 \mathrm{~m} \\
15 \mathrm{~m}\end{array}$ & $\begin{array}{l}\text { Jalur } \\
\text { Alun- } \\
\text { alun }\end{array}$ \\
\hline 6 & RSUD & $\begin{array}{l}\text { 1. Jalur } \\
\text { Alun-alun } \\
\text { 2. Jalur } \\
\text { Rama } \\
\text { Agung } \\
\text { 3. Jalur } \\
\text { Bandaran }\end{array}$ & $\begin{array}{l}8 \mathrm{~m} \\
6 \mathrm{~m} \\
8 \mathrm{~m}\end{array}$ & $\begin{array}{l}\text { Jalur } \\
\text { Rama } \\
\text { Agung }\end{array}$ \\
\hline
\end{tabular}

\section{KESIMPULAN DAN SARAN}

\section{A. KESIMPULAN}

Berdasarkan penelitian yang telah dilakukan maka dapat diambil kesimpulan sebagai berikut :

1. Berdasarkan hasil pengujian sistem yang dibuat : Pemda waktu tempuh 10 menit jalur terpendek gunung alam, Capil waktu tempuh 10 menit jalur terpendek karang suci, Porles waktu tempuh 8 menit jalur terpendek bundaran, Pemadam Kebakaran waktu tempuh 10 menit jalur terpendek alun - alun, Pln waktu tempuh 10 menit jalur terpendek alun - alun, Rsud waktu tempuh 6 menit jalur terpendek Rama Agung.

2. Adapun jalur terpendek bisa saja jarak tempuhnya lebih lama di karena keramaian dan kepadatan kependuduk.

3. Untuk menjalankan sistem ini di butuhkan jaringan internet yang memadai.

\section{B. SARAN}

Membuat akses peta dengan peta offline, diharapkan penelitian selanjutnya tidak hanya 6 titik melainkan banyak titik.

\section{Daftar Pustaka}

[1] Kusumawati kiki. “ Travellling Salesman Problem Pendistribusian Barang Menggunakan Algoritma Greedy “, Jurnal Ilmiah Fakultas Teknik, 2017

[2] Ghozali Eriq Akhmad, Setiawan Darma Budi , Tanzil Furqon, M. 'Aplikasi Perencanaan Wisata di Malang Raya dengan Algoritma Greedy “, Fakultas Ilmu Komputer, Universitas Brawijaya, 2017.

[3] Hartanto Fajar dan Yulia Safitri “ Rancang Bangun Aplikasi Pencarian Alokasi Wisata Kota Bogor Menggunakan Algoritma Greedy Berbasis Android “, Jurnal tekno Mandiri, Vol. XI, September 2014.

[4] Hayati Nur Enty dan YohanesAntoni, Pencarian Rute Terpendek MenggunakanAlgoritma Greedy, Seminar Nasional JENACO, , ISSN 2337-4347, 2014.

[5] Rofiq.M dan Uzzy Fathul Riza “ Penentuan Jaur Terependek Menuju Kafe di Kota Malang Menggunakan Metode Bellman-Ford dengan Location Based Service Berbasis Android, JurnalIlmia Teknologi dan Informasi ASIA, Vo 8 No 2, Agustus 2014

[6] Juniansyah Aldino dan Mesterjon “ Aplikasi Penentuan Rute Terpendek Untuk BagianPemasaran Produk RotiSurya dengan MetodeBset First Search “, Jurnal media Infotama, Vol 12 No 1, Februari 2016.

[7] Fauzi Imron " PenggunaanAlgoritma Dijkstra Dalam Pencarian Rute Tercepat dan Rute Terpendek (Studi Kasus Pada jalanRaya Antar Wilayah Blok M dan Kota) “, Skripsi, Progrman studi Teknik Informatika, Fakultas Sain dan Teknologi, Universitas Islam Negeri Syarif Hidayatullah, 2011.

[8] Undang-Undang Nomor 56 Pasal 19 tentang Pembentukan Instansi Pemerintah.

[9] Alfarisi Wahyudinur “ Pencarian Jalur Terpendek Pengiriman BarangMenggunakan Algoritma Greedy 
(Studi Kasus Kantor Besar Medan) “, Jurnal Riset Komputer (JURIKOM), Vol. 3 No 1, Februari 2016.

[10] Alfeno Sandro dan Devi Cipta Eka Ririn “ Implmentasi Global PositioningSystem (GPS) dan Loction Based Service (LBS) Pad Sistem Infomasi Kereta Api Untuk Wilayah Jabodetabek, Jurnal Sisfotek Global, Vol. 7 No. 2, September 2017. 